\title{
東日本大震災における「主体的な津波避難」に関する考察 一山田町·旧石巻市域での比較分析一
}

\author{
市古太郎 ${ }^{1)}$ \\ 1) 正会員 首都大学東京 都市システム科学域 准教授 博士(都市科学) \\ e-mail : ichiko-taro@tmu.ac.jp
}

\begin{abstract}
要 約
本研究は内閣府中央防災会議津波避難WGが基本方針として示した「迅速かつ主体的な避 難」に着目し「主体的な」避難行動の多臭が，各地域における「自然環境」ならびに「地 域社会」との相互作用として規定される面もあると考光, 東日本大震災津波避難合同調查 団＜山田町・石巻市＞のデータを用いてこれを検証したものである.

結論として宮城県旧石巻市域と比べて岩手県山田町において「主体的な避難行動」に統 計的有意差があったことを確認した，その集団的差違は，なりわい（漁師）と海との関係 性，自然地形を体感する避難訓練といった「自然環境との相互作用」ならびに地域組織を 主体とする津波ハザードマップ活用の取り組みといった「地域社会とそこで暮らす個人の 相互作用」として考察できる見方を示した.
\end{abstract}

キーワード: 東日本大震災, 津波避難, 津波リテラシー, 岩手県山田町, 宮城県石巻市

\section{1.「主体的な津波避難」をめぐって}

2012年7月に内閣府中央防災会議「津波避難対策検討ワーキンググループ（以下，津波避難WG）」は, 「住民等一人ひとりの迅速かつ主体的な避難行動」を「津波避難対策の基本的考え方」と提起した ${ }^{1)}$. ここで「迅速」の意味は自明であるのに対し，「主体的な」については後述するように津波避難WGに おいて様々な意見が開示されている．しかしながら「今後の津波避難対策の具体の方向性」の中に「避 難行動を促寸情報の確実な伝達」や「主体的な避難行動を取る姿勢を醸成する防災教育の推進」が示さ れていることから津波避難WGの示す「主体的な」とは「発災前からのハザードに対する知識（リテラ シー）と発災後の様々な情報（「摇れを体感したら」という八ザード関知も含む多様な「情報」）を基 に避難行動を自己決定できること」にあると考えられる.

このような「主体的避難」に向けた自己決定能力，言い換えれば，津波避難リテラシーには様々な規 定要因があり，個人ごとに多䓖を有しょう。本研究ではそういった個人の多臭が「自然環境」ならびに

「地域社会」との「相互作用」として規定される面もあると考える. 寸なわち地域ごとの津波避難行動 の差違を確認した上で，その差違が自然環境ならびに地域社会との相互作用として規定されうることを 研究の作業仮説としたい，たとえば三陸沿岸集落の自然環境の主要素と言える「海」との平常時におけ る向き合い方が，非日常時の「津波」リテラシーにどう関係しているか，また過去の津波被害と地域集 落の再建経験の継承, 津波避難訓練といった地域自治組織を主体とした地域社会の取り組みは, そこで 暮らす個人に影響を与えていると考えられよう。

東日本大震災における津波避難調査としては，国主導の公的調査として3つの調査，すなわち(1)内閣 
府・気象庁・消防庁合同調查（2011年），(2)国土交通省調查（2011年），(3)内閣府津波避難WGの政府統 計調査（2012年）が実施・公表されてきた。このうち(1)の内閣府・気象庁・消防庁合同調查結果は，津 波避難WGの議論にも活用され（但しRawデータは未公開）ているが，主として津波避難の「個人間相 違」に焦点があたっており，集落（集団）間の相違については分析の余地があると思われる．また学術 的調査として日本地震工学会「津波などの突発大災害からの避難の課題と対策に関する研究委員会」メ ンバーを主体とした「東日本大震災津波避難合同調査団＜山田町・石巻市＞」現地調查があるが，現段 階では, 調査方法と単純集計を基本とした調査結果の全体像が示されたのみである2３)．一方，東日本大 震災の津波避難に関寸る既発表研究としては，村上ら ${ }^{4)}$ による名取市の調査報告，諫川・大野5) による 千葉県御宿町での避難行動を集落空間資源と合わせた研究，松本のによるいわき市における「民衆知」 を介した津波避難行動の予備的報告等があるが，複数かつ地域特性の異なる地区を対象とした分析は行 われていない。

そこで本研究は，内閣府ワーキング資料から「迅速かつ主体的な避難」の意味を整理した上で，津波 避難に関する学術調査である「東日本大震災津波避難合同調查団＜山田町・石巻市＞」調査結果を用い て，二地域間の差違を分析し，この差違を自然環境ならびに地域社会からの相互作用という視点から考 察するものである.

\section{2. 内閣府津波避難WGの段階的津波避難分類}

内閣府津波避難WGの公開議事録から「主体性」をめぐる議論を整理しておく.

まず「主体性」が基本方針には明確に位置づけられていない第1回会合(2010年12月24日)では,

・「避難のためには，適切な情報を迅速にタイミングよく発表伝達することが重要」

・「情報を受け取る側のトレーニングが必要であり，これは大きな論点とすべきである」

・「住民自身の自主的な判断が不可欠であり，・・情報を入手・意識できる状況をどう作るか」

といった「情報に基づく避難行動の自己決定」という意見が複数出されている，そして回を重ねる中 で

・「きちんとした情報を提供して，逃げなければならないという判断を付けてもらう。そういう教育 と情報が必要である」(第3回)

・「受け手の情報に対する考え方や情報の生かし方を育てていかないとどうにもならない」(第6回)

といった，避難行動に対する自己判断能力を高める方策への意見が出されている. そしてその一方，

・「情報に依存しないで，摇れで逃げる，沿岸にいれば，まずは大きな摇れを感じたら津波のことを 考えて逃げる．これをきちんと徹底することが大前提」(第3回)

といった「情報に頼らない」という意味での「主体的」避難行動という意見も出されている.

とはいえ津波避難WGは東日本大震災時の津波避難行動調査結果も参照しつつ，議論を重初第6回

WG(2012年5月23日)で「津波避難行動の段階的分類」モデルを提示した。すなわち津波避難判断を次の4 つの段階に区分した.

表 1 津波避難 WG の津波避難行動の段階的分類モデル(WG 第 6 回資料より)

\begin{tabular}{|c|c|}
\hline 1.早期自己判断 & 地震の摇れにより, 津波来襲の危険性を自ら判断 \\
\hline 2.情報に基づき避難判断 & $\begin{array}{l}\text { 津波警報や行政による避難のよびかけ等, 情報を基に } \\
\text { 避難を判断 }\end{array}$ \\
\hline 3.追従避難 & 他者からの呼びかけ・避難行動を踏まえての避難 \\
\hline
\end{tabular}

4.津波来襲·目撃による＼cjkstart津波の来襲を知り危険を感じて避難

この分類モデルから「迅速かつ主体的な避難」について整理しておこう. 第1に「迅速な」という視点 からも「早期自己判断」比率を高めていくことが基本目標とされる. 第2に「早期自己判断」能力は「津 
波来襲の危険性を自ら判断」とあるように，津波ハザードマップや避難訓練を通して自分たちのまちに

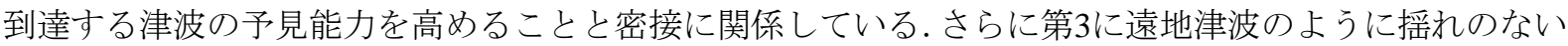
津波も想定すれば，摇れを体感しなくても，津波警報といった津波八ザード情報をキャッチし，情報を もとに一人ひとりが自分で判断する能力を高めること，すなわち「情報に基づく避難」も含めて「主体 的な避難行動」として提起されていると考えることができよう.

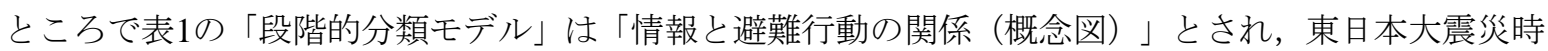
の津波避難行動による検証がおこなわれているわけではない，そこで次章以降，上記の避難判断モデル を実際の避難行動調查結果にあてはめ，地域間の差違に着目しながら「主体的な避難」について考察を 進めていくこととしたい.

\section{3. 東日本大震災津波避難合同調査団＜山田町 ·石巻市＞調査の調査方法について}

先述したように本研究は筆者も参加した「東日本大震災津波避難合同調査団＜山田町・石巻市＞」(以 下，津波避難合同調查団とする)の調查結果を用いた。調查概要は次表のとおりである.

表2 東日本大震災津波避難合同調査団＜山田町·石巻市 >による聞き取り調査概要

\begin{tabular}{|l|l|}
\hline 実施時期 & 2011 年 6 月から 12 月 \\
\hline 調査方法 & $\begin{array}{l}\text { 面接聞き取り調査（調査票をもとに聞き取り） } \\
\text { 調査員は, 地震津波工学の専門家, 研究者ら } 20 \text { 名弱. }\end{array}$ \\
\hline 調査数 & 564 人（山田町 222 人, 石巻市中心部 342 人） \\
\hline サンプリング方法 & 災害避難所・仮設住宅を訪問し, 調査依頼に同意をいただいた方. \\
\hline
\end{tabular}

そして表3は国主導の津波避難3調查の調查方法を整理したものである.この表2と表3を比証して, 津 波避難合同調査団による調查方法と調査データの特徵をまとめると次のようになる.

(1)調査実施時期は，内閣府・気象庁・消防庁合同調查と国土交通省調査とほぼ同一である．調査結果公 表前だったため，津波避難合同調查団の調查票設計にあたり，国主導調査の調查票を参照することは していない.

(2)サンプリング手法については，内閣府・気象庁・消防庁合同調查で用いられている「避難所・仮設住 宅を訪問し同意を得た方」と同一である.

(3)調查回答数については，総数で言えば津波避難合同調査団の調査数が最も少ないものの，山田町，石 巻市に限定して言えば，Rawデータにアクセスできる（2015年3月時点）国土交通省調査と比較して, 山田町ではほぼ同数であり, 石巻市では少なくなっている. また内閣府・気象庁・消防庁合同調査団 調査では岩手県で391名，宮城県で385名であり，山田町と石巻市に限って言えば，必ずしも津波避難 合同調査団の調査数が最も少ないとは言えないと考えられる.

表3 国主導の東日本大震災時の津波避難調査の概要

\begin{tabular}{|c|c|c|c|}
\hline & 内閣府·気象庁·消防庁合同調査 & 国土交通省調査 & 津波避難に関する政府統計調査 \\
\hline 実施時期 & 2011 年 7 月 & 2011 年 9 月～12月 & 2012 年 8 月 \\
\hline 調査方法 & 面接聞き取り & 面接聞き取り & 調査票調査 \\
\hline 調査回答数 & $\begin{array}{l}870 \text { 名 } \\
\text { 山田町, 石巻市の数は未公表 }\end{array}$ & \begin{tabular}{|l|}
9,574 名 \\
山田町 253 名, 石巻市 1,657 名
\end{tabular} & $\begin{array}{l}11,400 \text { 通 } \\
\text { 山田町, 石巻市の数は未公表 }\end{array}$ \\
\hline サンプリング手法 & $\begin{array}{l}\text { 避難所・仮設住宅を訪問し同意 } \\
\text { を得た方. 結果として, 岩手 } 391 \\
\text { 名, 宮城 } 385 \text { 名, 福島 } 94 \text { 名 }\end{array}$ & $\begin{array}{l}\text { 青森·岩手·宮城·福島·茨城·千 } \\
\text { 葉の } 6 \text { 県. 浸水区域内に居住し } \\
\text { ている個人(約 } 60 \text { 万人)をサンプ } \\
\text { リング(約 } 1.5 \%)\end{array}$ & $\begin{array}{l}\text { 1つの字・町丁目から概ね } 30 \\
\text { 人の方への調査依頼を想定し, } \\
\text { それぞれの市町村毎で、ご協力 } \\
\text { をお願いする字・町丁目の数を } \\
\text { 設定. }\end{array}$ \\
\hline
\end{tabular}


(4)調査方法として，内閣府・気象庁・消防庁合同調查および国土交通省調查と同様，「面接聞き取り」 方式である．加えて合同調査団調査は災害専門家・研究者が調査員となったことに対し，国土交通省 調査では現地住民といった非専門家も「調査員」に含まれていたようである.

また後藤ら ${ }^{3)}$ は, 合同調查団の回答データを2010年国勢調查結果と比証し, 年齢性別区分からみて山 田町では男性の60代と女性の50代および70代が多いこと，同様に石巻本庁地区では男性の60代および70 代，女性の60代以上が多く，男性の 40 代以下が特に少ないこと，職業区分からみて，山田町，石巻本庁 地区いずれも「漁師」の回答比率が高いこと等を指摘している，なお，以下本論では後藤233!合わせ， 石巻市のデータを平成合併前の石巻市域を意味する「石巻本庁管内」という名称で用いる.

表 4 回答者の職業

\begin{tabular}{|l|l|l|l|l|l|l|l|}
\hline & 回答数 & 漁師 & 農業 & 商店 & 勤め人 & その他 & 無職 \\
\hline 山田町 & 216 & $14.4 \%$ & $0.9 \%$ & $3.2 \%$ & $20.4 \%$ & $13.0 \%$ & $48.6 \%$ \\
\hline $\begin{array}{l}\text { 石巻本 } \\
\text { 庁管内 }\end{array}$ & 355 & $4.2 \%$ & $0 \%$ & $3.4 \%$ & $28.7 \%$ & $6.1 \%$ & $56.4 \%$ \\
\hline
\end{tabular}

表 5 避難行動有無

\begin{tabular}{|l|r|r|}
\hline & 避難した & 避難なし \\
\hline 山田町 & 191 人(84.3\%) & 25 人(11.6\%) \\
\hline $\begin{array}{l}\text { 石巻本 } \\
\text { 庁管内 }\end{array}$ & 271 人(76.3\%) & 84 人(23.7\%) \\
\hline
\end{tabular}

\section{4. 山田町と旧石巻市 (石巻本庁管内) での「主体的な避難」に関する分析}

本章では津波避難合同調查団のデータを用いて，「主体的な避難」という視点から津波避難行動を分 析する．なお国交省復興支援調査アーカイブより，山田町と石巻本庁管内両地区の最大浸水深は $8.7 \mathrm{~m}$ (山 田町船越) 16.4m(山田町中央町), $5.9 \mathrm{~m}$ (石巻市南浜町), また津波到達時間は32 分(山田町中央町), 56 分 (石巻市南浜町)であった. 石巻本庁管内は津波避難WG とは別の内閣府「東北地方太平洋沖地震を教訓と した地震・津波対策に関する専門調査会」専門調査会（2011年）でも「津波八ザードマップと今回の浸 水区域の乘離が大きかった地域」として例示されているのに対し，山田町では地形の関係からも東日本 大震災発災前の津波八ザードマップとの乘離が相対的にみて小さい地域の1つである.

またリアス式海岸と平場のある海岸という「自然環境」の相違，宮城県と岩手県という「地域社会」 特性の相違から本研究の主題に照らして比較分析が有効であると考えた.

表5は津波避難合同調查団のデータにおける避難行動有無である. 自宅が高台にあったケースに加えて 職場に居て避難不要だったといった方も「避難なし」に含まれる. 内閣府・気象庁・消防庁合同調查で は避難していないケースは $1.5 \%$, 国交省調査では26.8\%である.

\section{(1)津波避難行動の段階的分類}

表6は「避難を判断した最も大きな要因」を尋ねた結果である．表中に示すように表1の避難段階類型

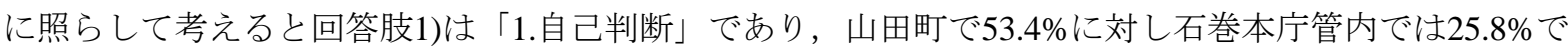
ある. また表6の回答肢2)と3)は「2.情報に基づき避難」に該当する類型であり，山田町では2)と3)を合 わせて $16.8 \%$, 石巻本庁管内では $38.3 \%$ と石巻で高い. そして回答肢4)と5)は「3.追従避難」に該当寸る が「5)近所の人から促されたから」という回答は石巻本庁管内で高くなっている．そして選択肢6),7),8) は「4.津波来襲・目撃による避難」であり, 山田町の方が高い割合(13.6\%)となっている.

帰無仮説 $\mathrm{H}$ : 山田町と石巻本庁管内の避難行動類型比率には一致性がある, は $\mathrm{p}<0.001$ で棄却され，両 地域間の避難判断類型には統計的な差違が確認された。つまり山田町では摇れを感じての「1. 早期自己 判断」と「4.津波来襲・目撃による」が避難対処行動への直接要因となったのに対し, 石巻本庁管内で は「2.情報に基づく避難」と「3.他者からの働きかけ(追従避難)」が最大要因となっていた.

次に表7は避難開始までの行動について複数回答で尋ねた結果である. 表6の避難判断類型と比較して, 両地区で大きな差違はないことが見て取れる。ここで本研究の主題とは外れるが，2)と3)の回答が示す 「家族を迎えに」という行動パターンが山田町で14.2\%，石巻本庁管内で15.8\%あることには注目してお きたい. 
表 6 (避難した人のうち)避難を判断した最も大きな要因

\begin{tabular}{|c|c|c|c|c|c|}
\hline \multirow{2}{*}{$\begin{array}{l}\text { 内閣 WG 類型 } \\
\text { 1. 早期自己判断 }\end{array}$} & \multirow{2}{*}{$\begin{array}{l}\text { 調査団の回答肢 } \\
\text { 1)大きな摇れを感じ, 津波が来ると思ったから }\end{array}$} & \multicolumn{2}{|c|}{ 山田町 (N=191) } & \multicolumn{2}{|c|}{ 石巻本庁 $(\mathrm{N}=271)$} \\
\hline & & 102 & $53.4 \%$ & 70 & $25.8 \%$ \\
\hline \multirow{2}{*}{$\begin{array}{l}\text { 2. 情報に基づき } \\
\text { 避難判断 }\end{array}$} & $\begin{array}{l}\text { 2) 大きな津波が来るとの警報や避難指示を（行政による放送、ラ } \\
\text { ジオ、サインン、テレビ、メールなどか）を聞いたから }\end{array}$ & 20 & $10.5 \%$ & 58 & $21.4 \%$ \\
\hline & 3）家族が避難しようと言ったので & 12 & 6. $3 \%$ & 46 & $16.9 \%$ \\
\hline \multirow{2}{*}{ 3. 追従避難 } & 4)近所の人が避難をはじめたから、避難する人を見たから & 7 & 3. $7 \%$ & 13 & 4. $8 \%$ \\
\hline & 5)近所の人や町内会・自主防災組織から避難を促されたから & 11 & 5. $8 \%$ & 37 & 13. $6 \%$ \\
\hline \multirow{4}{*}{$\begin{array}{l}\text { 4. 津波来襲・目撃 } \\
\text { により }\end{array}$} & 6) 引き潮を見たから、あるいはそう聞いたから & 2 & $1.0 \%$ & 0 & $0.0 \%$ \\
\hline & 7) 津波が来るのが見えたから、あるいは異常な音が聞こえた & 20 & $10.5 \%$ & 13 & 4. $8 \%$ \\
\hline & $\begin{array}{l}\text { 8) 津波が堤防を越えて地区に入ってきたのを見たからあるいは } \\
\text { そう聞いたから }\end{array}$ & 4 & 2. $1 \%$ & 4 & 1. $5 \%$ \\
\hline & 9) その他 & 13 & 4. $8 \%$ & 28 & 10. $3 \%$ \\
\hline
\end{tabular}

左は回答数, 2 地域間の回答数の独立性検定結果: $\mathrm{p}<0.01 * *$

表 7 (避難した人)避難開始までに取った行動（複数回答）

\begin{tabular}{|c|c|c|c|c|}
\hline \multirow[b]{2}{*}{ 1) 勤務先や外出先から一度自宅に戻った（大切な物を持ち出すため） } & \multicolumn{2}{|c|}{ 山田町 (N=191) } & \multicolumn{2}{|c|}{ 石巻本庁 $(\mathrm{N}=271)$} \\
\hline & 31 & 16. $2 \%$ & 40 & $14.8 \%$ \\
\hline 2) 外出先から自宅に家族を迎えに行った（家族の避難を手助けするため） & 16 & 8. $4 \%$ & 22 & 8. $1 \%$ \\
\hline 3）家族を迎えに行った（学校や施設などへ） & 11 & 5. $8 \%$ & 21 & 7. $7 \%$ \\
\hline 4)海の様子を見に行った & 12 & $6.3 \%$ & 4 & $1.5 \%$ \\
\hline 5) 避難のための荷物（現金・通帳 · 印鑑、食料、薬、ラジオなど）をまとめた & 78 & $40.8 \%$ & 96 & $35.4 \%$ \\
\hline 6)戸締まりをした & 29 & 15. $1 \%$ & 26 & $9.6 \%$ \\
\hline 7) 地震で散らかった家具や機材を片付けた & 17 & 8. $9 \%$ & 62 & $22.9 \%$ \\
\hline 8）家族や知人に電話（メール）をかけた & 7 & 3. $7 \%$ & 13 & 4. $8 \%$ \\
\hline 9)覚えていない & 3 & $1.6 \%$ & 13 & 4. $8 \%$ \\
\hline 10)何もせず直ぐに避難をはじめた & 46 & $24.1 \%$ & 74 & $27.3 \%$ \\
\hline 11) 周囲に声をかけていた & 4 & $2.1 \%$ & 38 & $14.0 \%$ \\
\hline 12）要介護者の避難の手助けをしていた & 9 & 4. $7 \%$ & 15 & $5.5 \%$ \\
\hline
\end{tabular}

表 8 避難時の人数(同行者)(複数回答)

\begin{tabular}{|l|r|r|r|r|}
\hline & \multicolumn{2}{|c|}{ 山田町 } & \multicolumn{2}{|c|}{ 石巻本庁 } \\
\hline 1)自分ひとりで & 66 & $34.5 \%$ & 71 & $26.2 \%$ \\
\hline 2)家族といっしょに & 111 & $58.1 \%$ & 171 & $63.1 \%$ \\
\hline 3)同僚や同じ職場の人 & 14 & $7.3 \%$ & 28 & $10.3 \%$ \\
\hline 4)近所の人 & 22 & $11.5 \%$ & 59 & $21.8 \%$ \\
\hline 5)学校で一緒にいた人 & 2 & $1.0 \%$ & 4 & $1.5 \%$ \\
\hline 6)避難を誘導した人 & 1 & $0.5 \%$ & 4 & $1.5 \%$ \\
\hline 7)その他 & 7 & $3.7 \%$ & 3 & $1.1 \%$ \\
\hline
\end{tabular}

表 9 避難行動時の未避難者への声かけ状況

\begin{tabular}{|l|r|r|r|r|}
\hline & \multicolumn{3}{|c|}{ 山田町 } & \multicolumn{2}{|c|}{ 石巻本庁 } \\
\hline 1)声をかけた & 80 & $41.9 \%$ & 102 & $37.6 \%$ \\
\hline 2)かけなかった(余裕なし) & 97 & $50.8 \%$ & 148 & $54.6 \%$ \\
\hline 3)覚えていない & 11 & $5.8 \%$ & 17 & $6.3 \%$ \\
\hline 4)声をかけ, 避難を手助け & 3 & $1.6 \%$ & 4 & $1.5 \%$ \\
\hline
\end{tabular}


表 8 は一緒に避難した人数についての回答である. 山田町で「自分 1 人で」の割合が高い $(34.5 \%)$ こ， 石巻本庁管内で「近所の方と一緒に」という回答が多い(21.8\%)ことがわかる．「家族といっしょに」の 回答については，大きな差違はみられない。

\section{(2)他者への「声かけ」行動}

追従の別側面としての「他者への声かけ」について「避難行動中にまだ避難していない人に声をかけ ましたか?」と尋ねた結果が表9である。「声をかけた」+「声をかけると共に避難の手助けをした」と

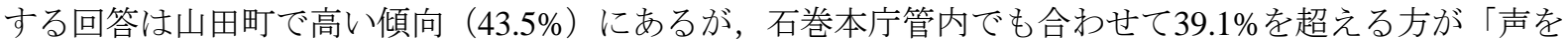
かけた」と回答している.

\section{(3)津波来襲危険性の察知}

表10は津波来襲危険性の察知についての結果である．1)大きな被害が出る津波が来ると思った，とい う回答が山田町 $39.4 \% に$ 対して石巻本庁管内は $14.6 \%$ ，一方4)津波のことはほとんど考えなかった，とい う回答が山田町で $8.8 \%$ に対し石巻本庁管内は $30.7 \%$ に達している. 山田町と石巻本庁管内で差違がある ことが見て取れる。ここで表11は国交省調查の設問3の集計結果である.4)津波のことはほとんど考えな かった比率について，津波避難合同調査団の山田町と石巻市それぞれの比率と同じ傾向にあることがわ かる.

表12は摇れが収まった直後時点でのリードタイム（津波到達予想時間）の認識である. 両地区とも「考

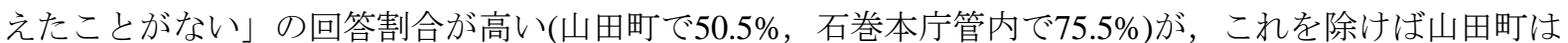

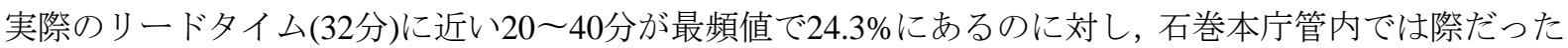
モードはなく，また東日本大震災時の実際の津波到達時間（56分）と考えた方は1.7\%と少ない．

表 10 発災直後の津波来襲意識

\begin{tabular}{|l|c|c|c|c|}
\hline & \multicolumn{2}{|c|}{ 山田町 } & \multicolumn{2}{|c|}{ 石巻本庁 } \\
\hline $\begin{array}{l}\text { 1)大きな被害が出るような津波が来 } \\
\text { ると思った }\end{array}$ & 86 & $39.4 \%$ & 52 & $14.6 \%$ \\
\hline $\begin{array}{l}\text { 2)来るとは思ったが、あれほど大き } \\
\text { な津波が来るとは思わなかった }\end{array}$ & 94 & $43.1 \%$ & 121 & $34.1 \%$ \\
\hline $\begin{array}{l}\text { 3)津波は来ないだろうと思った } \\
\text { 4)津波のことはほとんど考えなかっ } \\
\text { た }\end{array}$ & 17 & $7.8 \%$ & 73 & $20.6 \%$ \\
\hline
\end{tabular}

表 11 発災直後に居た場所に津波が来ると思ったか(国交省調查)

\begin{tabular}{|l|c|c|c|c|}
\hline & \multicolumn{2}{|c|}{ 山田町 } & \multicolumn{2}{|c|}{ 石巻市s } \\
\hline $\begin{array}{l}\text { 1)津波は必ず来ると思 } \\
\text { った }\end{array}$ & 153 & $60.5 \%$ & 525 & $31.4 \%$ \\
\hline $\begin{array}{l}\text { 2)津波は来るかもしれ } \\
\text { ないと思った }\end{array}$ & 41 & $16.2 \%$ & 236 & $14.1 \%$ \\
\hline $\begin{array}{l}\text { 3)津波は来ないだろうと } \\
\text { 思った }\end{array}$ & 37 & $14.6 \%$ & 362 & $21.6 \%$ \\
\hline $\begin{array}{l}\text { 4)津波のことはほとんど } \\
\text { 考えなかった }\end{array}$ & 22 & $8.7 \%$ & 534 & $31.9 \%$ \\
\hline
\end{tabular}

表 12 発災時点での津波到達見込み時間

\begin{tabular}{|l|c|c|c|c|}
\hline & \multicolumn{2}{|c|}{ 山田町 } & \multicolumn{2}{|c|}{ 石巻本庁 } \\
\hline 1)5 分未満 & 14 & $6.3 \%$ & 8 & $2.3 \%$ \\
\hline 2)5〜10 分未満 & 17 & $7.7 \%$ & 19 & $5.4 \%$ \\
\hline 3)10～20 分未満 & 13 & $5.9 \%$ & 23 & $6.5 \%$ \\
\hline 4)20～40 分未満 & 54 & $24.3 \%$ & 26 & $7.3 \%$ \\
\hline 5)40～1 時間未満 & 10 & $4.5 \%$ & 6 & $1.7 \%$ \\
\hline 6)1 時間以上 & 2 & $0.9 \%$ & 5 & $1.4 \%$ \\
\hline 7)考えたことはなかつた & 112 & $50.5 \%$ & 268 & $75.5 \%$ \\
\hline
\end{tabular}




\section{(4)津波ハザードマップ・家族話し合い - 避難訓練参加度}

山田町における津波到達リードタイムの一致（回答者の $24.3 \% か ゙ 「 20$ 分〜 40分」と回答）の要因とし て, 津波浸水想定区域図ないし津波八ザードマップの影響も考えられる。ここで, 表13は津波八ザード マップの認知・活用についてである．津波八ザードマップを「見たことはある」とする回答は(「2)見た ことはあるが参考にしたことはない」も含めて)山田町で高く(41.4\%), 逆に石巻本庁管内では「3)見たこ とはなかった」という回答が $68.5 \%$ に達している(山田町では41.0\%). 内閣府専門調査会でも紹介されて いるように石巻市中心部は，津波ハザードマップと東日本大震災時の津波浸水区域の乘離が大きかった ケース（想定を大きく上まわる地域が浸水した）であり，逆に山田町は岩手県が東日本大震災以前に公 表していた津波想定浸水区域との乘離が小さかった地域である。加えて山田町の津波想定図には「最大 波到達時間」が示され，山田湾においては最短で28分と記されているが，東日本大震災で堤防を超えて 山田町中心部に津波が入ってきたのは発災から32分後の15:18であり，到達時間，言い換えれば，対処行 動できる時間感覚について住民の多くに，石巻本庁管内と比べれば「合っていた」と感じた面があった のではないか, と推察される.

表 13 津波ハザードマップの認知と活用状況

\begin{tabular}{|l|r|r|r|r|}
\hline & \multicolumn{2}{|c|}{ 山田町 } & \multicolumn{2}{|c|}{ 石巻本庁管内 } \\
\hline $\begin{array}{l}\text { 1)見たことがあり、自分の居場所の安全性や避難場所と避難経 } \\
\text { 路を考えたことがある。 }\end{array}$ & 50 & $22.5 \%$ & 29 & $8.2 \%$ \\
\hline 2)見たことはあるが、参考にしたことはない。 & 42 & $18.9 \%$ & 41 & $11.5 \%$ \\
\hline 3)見たことはなかった & 91 & $41.0 \%$ & 243 & $68.5 \%$ \\
\hline 4)覚えていない & 20 & $9.0 \%$ & 25 & $7.0 \%$ \\
\hline
\end{tabular}

また津波避難判断に影響を与えた要因として，表14は「家族で津波について話し合ったことはありま すか」という設問に対する回答で，山田町では半数の $50.9 \%$ の帯で「1)話し合って避難先や連絡方法を 決めていた」と回答している. 逆に石巻本庁管内では「4)全く話したことがない」という回答で33.5\% (山 田町では8.6\%) となっている.

表 14 事前の家族での避難に関する話し合い状況

\begin{tabular}{|l|r|r|r|r|}
\hline & \multicolumn{2}{|c|}{ 山田町 } & \multicolumn{2}{|c|}{ 石巻本庁管内 } \\
\hline 1)話し合って、避難先や連絡方法を決めていた & 113 & $50.9 \%$ & 111 & $31.3 \%$ \\
\hline 2)話し合ったことはあるが、どうするかまでは決めていなかった & 27 & $12.2 \%$ & 31 & $8.7 \%$ \\
\hline 3)ほとんど話したことがない & 34 & $15.3 \%$ & 53 & $14.9 \%$ \\
\hline 4)全〈話したことがない & 19 & $8.6 \%$ & 119 & $33.5 \%$ \\
\hline 5)一人で生活していた & 10 & $4.5 \%$ & 24 & $6.8 \%$ \\
\hline 無回答 & 19 & $8.6 \%$ & 17 & $4.8 \%$ \\
\hline
\end{tabular}

表15は地域防災訓練への参加状況を, また表16は発災前までの防災訓練が「今回の津波避難に役に立 ったと思いますか」と聞いた結果である．山田町で防災訓練への参加率が高く，またこれまでの防災訓 練を肯定的に捉えている方が多い傾向にあった. 
表 15 地域防災訓練への参加状況

\begin{tabular}{|l|c|c|c|c|}
\hline & \multicolumn{2}{|c|}{ 山田町 } & \multicolumn{2}{c|}{ 石巻本庁 } \\
\hline 1)ほぼ毎年参加していた & 83 & $37.4 \%$ & 62 & $17.5 \%$ \\
\hline 2)時々参加していた & 33 & $14.9 \%$ & 26 & $7.3 \%$ \\
\hline $\begin{array}{l}\text { 3)参加したことがあるがここ } \\
\text { 数年は参加していない }\end{array}$ & 22 & $9.9 \%$ & 25 & $7.0 \%$ \\
\hline 4)参加したことはない & 66 & $29.7 \%$ & 209 & $58.9 \%$ \\
\hline 無回答 & 18 & $8.1 \%$ & 33 & $9.3 \%$ \\
\hline
\end{tabular}

表 16 防災訓練の有効性

\begin{tabular}{|l|c|c|c|c|}
\hline & \multicolumn{2}{|c|}{ 山田町 } & \multicolumn{2}{c|}{ 石巻本庁 } \\
\hline 1)大変役に立った & 45 & $20.3 \%$ & 10 & $2.8 \%$ \\
\hline 2)役にたった & 49 & $22.1 \%$ & 29 & $8.2 \%$ \\
\hline 3)何とも言えない & 55 & $24.8 \%$ & 108 & $30.4 \%$ \\
\hline 4)役に立たなかつた & 34 & $15.3 \%$ & 112 & $31.5 \%$ \\
\hline $\begin{array}{l}\text { 5)防災訓練の避難先が安全では } \\
\text { なかったので、役に立たなかった }\end{array}$ & 3 & $1.4 \%$ & 2 & $0.6 \%$ \\
\hline 6)わからない, 無回答 & 36 & $16.2 \%$ & 94 & $26.5 \%$ \\
\hline
\end{tabular}

\section{5.「迅速かつ主体的な津波避難」に関する知見と「相互作用」の視点からの考察}

本研究は「迅速かつ主体的な避難」という視点から, 避難生活をされている方へのインタビュー調查 をもとに，東日本大震災時の津波避難行動の分析をおこなった．得られた知見は次のようになる.

(1)内閣府津波避難WGが示した「津波避難の段階的分類モデル」の4分類を山田町と石巻本庁地区で示し た(表6). 津波避難WGが提起する「早期自己判断」は山田町で $53.4 \%$ ，石巻本庁地区で $25.8 \%$ ，その差 は統計的に有意であった。

(2)発災直後の津波来襲予見(表10)も山田町で「大きな被害が出るような津波がくると思った」と感じた

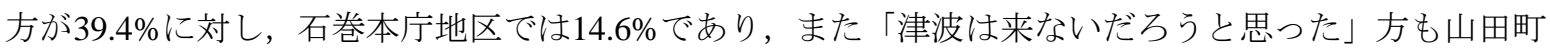
の7.8\%に対し，石巻本庁地区は20.6\%と，山田町での津波来襲予見意識が高くなっていた。

以上の結果は津波避難WGが示唆した「発災前・発災後の様々な情報に基づいて津波来襲をイメージ し避難行動を自己決定する」という「迅速かつ主体的な避難」が，石巻本庁地域に比べて山田町におい て多く作動したことを示していると言えよう.

次にこういった山田町と石巻本庁管内の行動差違について, 本研究で主題とした「自然環境ならびに 地域社会との相互作用」の視点から考察すれば次のようになる.

(3)「自然環境」との相互作用として, 自然現象としての両地区の津波到達高さは石巻本庁で $5.9 \mathrm{~m}$ に対し, 山田町中央で $16.4 \mathrm{~m}$ と山田町で高いものの，山田町は多くの集落で駆け上れる後背斜面地を有し，逆 に石巻本庁管内は海に接して平坦な土地が広がっていた。そして山田町では徒歩避難を原則とする地 域防災訓練の参加率ならびに避難訓練に対する主観的有効性評価が石巻本庁管内と比べて高く, 実際, 合同調查団データでは，徒歩のみの避難割合が山田町で $53.4 \%$, 石巻本庁で $41.3 \%$, 一方で自動車利用 割合は山田町で $40.0 \%$, 石巻本庁で $52.6 \%$ と山田町において徒歩避難率が高くなっている. 以上のこと から, 山田町において徒歩避難訓練といった事前準備策を通じ, 徒歩避難可能な地形環境が認知され, 津波来襲時，徒歩避難する自己行動イメージ形成につながっていた，と推察できよう.

加えて職業回答における漁師の比率に着目してみよう。表4から漁師比率は山田町で14.4\%, 石巻本

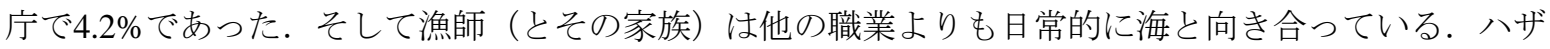
ードマップ活用に関する先行研究でも指摘されているように ${ }^{1}$, 日常的な自然環境との向き合い方は, 自然環境の非日常時のイメージを持とうとする意識につながっていたと考えられる．言い換えれば, 三陸沿岸集落において，なりわいを介した沿岸環境との相互作用として非日常時の津波イメーシ醸成 につながっていたことが示唆されよう。

1文献7)によれば，荒川下流部の調査結果によれば，平常時に「かわ」を意識しているほど洪水ハザードマップ認 知，言い換えれば非日常時の「自然」に対する関心も高い傾向が得られている. 
(4)地域社会との相互作用として，まず「津波ハザードマップを見て自宅の安全性や避難場所について考 えたことがある」という回答は，山田町で $22.5 \%$ に対し石巻本庁管内で $8.2 \%$ と山田町で認知活用水準 が高い. 後藤ら ${ }^{3)}$ も報告しているが，山田町では，町内を7つに区分して「住民参加型ハザードマップ」 づくりが進められていた。 津波八ザードマップ認知は, このような行政と地域組織による地域防災活 動との相互作用の結果と考えられよう。また地域防災訓練についても「ほぼ毎年参加」が山田町で 37.4\%に対し石巻本庁管内では $17.5 \%$ に留まっていたこと, 「防災訓練は今回の津波避難に役立った か?」という問いに対して, 山田町では $42.4 \% か ゙$ 肯定的な回答で, 石巻本庁管内での $11.0 \%$ ときな差 違が出ていたこと，さらに山田町における津波避難に向けた「家族の話し合い」水準の高さ（表14） も合わせて勘案すれば，地域組織の津波避難に向けた取り組みが個人の「迅速かつ主体的な避難」行 動を高めていた，と言えよう。

今後の研究課題として, 自然環境と地域社会との相互作用という本研究の作業仮説は試論的な面を有 しており，災害時行動に関する理論および東日本大震災時の避難行動実態調査の両面から掘り下げる心゙ き点を有している．また各集落ごとの東日本大震災発災以前の津波避難に関寸る取り組み，過去の津波 被害と集落再建に関する伝承，といった点も含めて比較分析していくことが考えられよう.

\section{謝 辞}

本稿の作成においては，東日本大震災津波避難合同調査団での一連の活動，日本建築学会広域避難小 委員会, 日本地震工学会「津波等の突発大災害からの避難の課題と対策に関する研究委員会」での研究 会と議論に依るところが大きい，これらの委員会活動に改めて御礼申し上げたい.

\section{参考文献}

1) 内閣府 : 津波避難対策検討ワーキングループ報告および会議資料、2012年.

2) 後藤洋三、池田浩敬、市古太郎、他10名 : 東日本大震災津波避難合同調査団の形成と山田町 - 石巻市 担当チームによる調查結果-調査概要編一、日本地震工学会論文集、特集号「津波等の突発大災害からの 避難の課題と対策」、第15巻、第5号、2015年、pp.97-117.

3) 後藤洋三、池田浩敬、市古太郎、他10名 : 東日本大震災津波避難合同調査団の形成と山田町 - 石巻市 担当チームによる調査結果-データ特性分析編一、日本地震工学会論文集、特集号「津波等の突発大災害 からの避難の課題と対策」、第15巻、第5号、2015年、pp.118-143.

4) 村上ひとみ：2011年東日本大震災による名取市の人的被害と避難遅れ影響要因-被害統計と津波避難 アンケートの分析-、地域安全学会論文集No.24、2013年、pp.101-110.

5) 諫川輝之、大野隆造 : 住民の地域環境に対する認知が津波避難行動に及ぼす影響一千葉県御宿町の事 例から一、日本建築学会計画系論文集705号、2014年、pp.2405-2413.

6) 松本行真 : 地域で形成される民衆知と津波避難に関する予備的考察一福島県浜通り地方を事例に一、 地域安全学会論文集No.21、2013年、pp.119-128.

7) 市古太郎、木村美瑛子、加藤孝明、石川金治、中林一樹 : 荒川下流左岸地域におけるハザードマップ 認知と広域避難率の向上に関する研究、日本都市計画学会学術研究論文集45、2010年、pp.289-294. 


\title{
A Discussion for "self-active Tunami Evacuation" in the Great East Japan Earthquake
}

- Comparative analysis between Yamada Town and Ishinomaki City-

\author{
ICHIKO Taro ${ }^{1)}$
}

1) Member, Associate Professor, Tokyo Metropolitan University, Dr. Urban Science

\begin{abstract}
In 2012, Cabinet Office, Government of Japan published a report "the counter measures of TUNAMI evacuation". This report proposed self-active TUNAMI evacuation. But actually, there are various opinions about "self-active TUNAMI evacuation”. In this paper, firstly, this Japan cabinets' report was summarized and reviewed. Secondly, comparative analysis relating with self-active evacuation in the great east Japan earthquake were shown. And finally, differentiates for self-active evacuation between Yamada Town and Ishinomaki City was discussed mainly as interaction among people, nature and local-community.
\end{abstract}

Keywords: The Great East Japan Earthquake, TUNAMI evacuation, self-active evacuation capacity, Yamada Town, Ishinomaki city 